\title{
骨移植後に二期的大腿骨頭前方回転骨切り術を施行した 特発性大腿骨頭壊死症（ION）の小治療経験
}

\author{
田中源幸* 堀川良治* 神直 純 一* \\ 栫 博 則* 石 堂 康 弘** 小宮 節 郎*
}

Experience of Four Cases who Underwent Transtrochanteric Anterior Rotational Osteotomy (ARO) after Bone Graft for Idiopathic Osteonecrosis of the Femoral Head (ION)

Motoyuki Tanaka*, Yoshiharu Horikawa*, Junichi Kamizono*, Hironori Kakoi*, Yasuhiro Ishidou**, and Setsuro Komiya*

特発性大腿骨頭壊死症（ION）の治療法の選択は病型・病期・患者背景（原疾患の有無・年齢・職業 etc.) に上る. 我々は若年患者の ION に対して人工骨（HA）移植後に二期的に大腿骨頭前方回転骨切り 術（ARO）を施行した症例を経験したので報告する。2 2005 年 12 月から 2006 年 9 月までに当科受診した ION で広範な壊死巣を伴う 10 代の女性 2 名, 20 代の女性 1 名, 30 代の男性 1 名であった。疾患は 4 例 ともにステロイド性，病期分類は Stage III，病型分類は type C であった。最終観察時，2 例は骨頭の圧 潰進行は認めなかった。 1 例は $5 \mathrm{~mm}$ の圧潰を認め, 1 例は $\mathrm{ARO}$ 術後の抜釘後 7 ヶ月目に移植骨周辺〜 頝部での骨折を認め THA 施行することとなった。

Treatment for patients with idiopathic osteonecrosis of the femoral head (ION) is decided according to disease type, stage, age, occupation, and background of the original disease. We report four young cases who underwent transtrochanteric anterior rotational osteotomy (ARO) of the femoral head after artificial bone-graft for idiopathic osteonecrosis (ION). Between December 2005 and September 2006, two teenage female patients, one female patient in her 20's, and one male in his 30's with extensive necrosis were studied. All four cases had stage 3, type C necrosis caused by steroid. In the last examination, two patients showed no progress of collapse and one patient showed $5 \mathrm{~mm}$ collapse. One patient sustained fracture of the femoral neck seven months after removal of the fixed screw, and underwent total hip arthroplasty (THA) for this.

Key words : idiopathic osteonecrosis of the femoral head (大腿骨頭壊死症), anterior rotational osteotomy of the femoral head (大腿骨頭前方回転骨切り術), total hip arthroplasty (人 工股関節置換術)

\section{は じめに}

特発生大腿骨頭壊死症（ION）の治療法の選択は病 型・病期・患者背景（原疾患の有無・年齢 - 職業 etc.）による. 青壮年期に好発する ION は関節温存 手術が望まれる疾患である。当科では, 若年患者で壊 死範囲が広範である ION に対して, 壊死部を掻爬し,
人工骨を支柱として移植後に二期的大腿骨頭前方回転 骨切り術（ARO）を施行した.

\section{対 象}

対象は 2002 年 6 月〜2006 年 9 月までに当院を初診 した 4 例で，いずれもステロイド投与例であり，病期 分類ではいずれも TypeC2 で，病型分類では 3 例が

\footnotetext{
* 鹿児島大学大学院運動機能修復学講座整形外科 Department of Orthopedics Surgery, Faculty of Medicine, Kagoshima University, Kagoshima, Japan

** 鹿児島大学大学院医療関節材料開発講座 Department of Medical Joint Materials (Japan Medical Materials), Graduate School of Medical and Dental Sciences, Kagoshima University, Kagoshima, Japan
} 

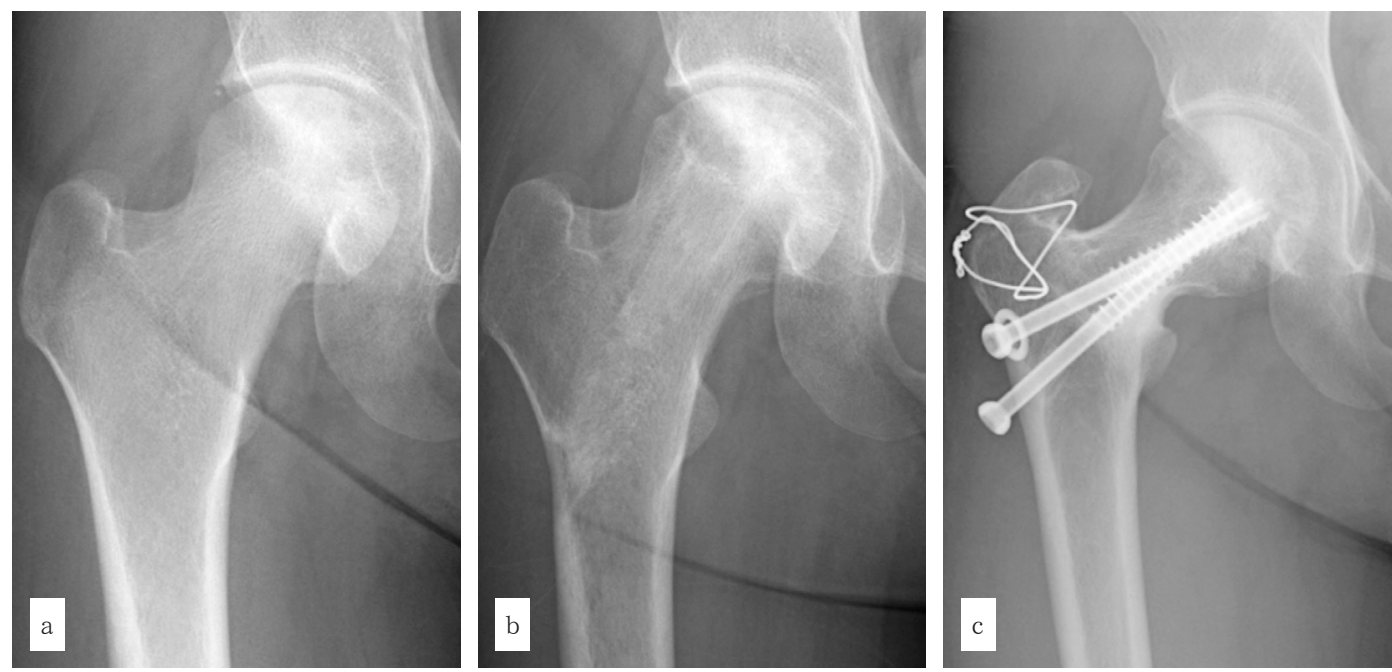

図 1 症例 1

29 歳 女性 潰瘍性大腸炎 Type C2 stage3A

a. 術前正面

b. 病巣掻爬 + 人工骨移植術後

c. b の術後 4 ヶ月, $\mathrm{ARO}\left(+\right.$ 内反 $10^{\circ}$ ) 施行 人工骨を含む健常域は $83 \%$

Stage 3 A， 1 例が Stage 3 B であった．原疾患は潰 瘍性大腸炎 (UC), 特発性血小板減少性紫斑病 (ITP), 原田病，SLEであった。

方

\section{法}

今回我々は壊死範囲が広範で術前検討にて $\mathrm{ARO}$ 施 行にて健常部占拠率が 34\%未満である者に対して， まず一期で病巣掻爬を関節鏡視下・イメージ下に，目 的とする健常部之壊死部境界へ東北大式骨髄生検針を 挿入し，壊死部の掻爬を行い，人工骨を充填した。人 工骨充填部を正常域と見なし，回転骨切り後の占拠率 を拡大しょうと試みた。 人工骨移植術後の約 4 ヶ月で 杉岡式 $90^{\circ}$ 前方回転骨切り術 ${ }^{6)}$ を行った。

\section{症 例 供 覧}

症例 1：29歳女性 潰瘍性大腸炎にてステロイド内 服加療. 治療後 8 年にて右股関節疼痛出現. 病型・病 期は Type C2 Stage 3A であった.

杉岡式前方回転骨切り術 $90^{\circ}$, 内反 $10^{\circ}$ 施行 経過は 良好で骨頭の圧潰所見はなく，球形を保っている (困 1 ).

症例 $2 ： 17$ 歳女性 血小板減少性紫斑病に対しステ ロイド内服. 治療後 1 年にて両股関節疼痛出現. MRI
上，両側の大腿骨頭壊死を認め，右股には広範な壊死 を示す T1Low band 認める病型・病期は Type C2, Stage 3A. ARO 術後の健常部占拠率は 84\%であった. 術後 3 年 5 ヶ月にて抜釘し骨頭の圧潰は認めない (困 2 ).

症例 3:39歳男性 原田病によるぶごう膜炎に対しス テロイド内服加療. 治療後 8 ヶ月にて両股関節疼痛出 現. MRIにて典型的な T1 Low band 認める. 病型・ 病期は右：Type C1 stage 3A 左：Type C2 stage 3A であった。

$\mathrm{ARO}$ 術後，健常部占拠率は $42 \%$ であった。 左 $\mathrm{ARO}$ 後 4 ヶ月にて右股関節疼痛増強, リハビリ効 率，強固な支持脚を作る目的にて，右 THA 施行。左 $\mathrm{ARO}$ 後 2 年にて抜釘施行し, 約 $5 \mathrm{~mm}$ の骨頭圧潰を 認める屯症状認めない（図 3 ).

症例 4：15 歳女性 SLEにてステロイド内服加療. 治療後 1 年後より両側股関節痛出現, 近医にて ION 指摘, 骨頭圧潰進行し, MRI にてかなり広範な T1 Low band を認めた。病型・病期は Type C2, Stage $3 \mathrm{~A}$ であった，移植骨を含んだ健常部が後方に $52 \%$ 存 在すると考え $\mathrm{ARO}$ 施行. $\mathrm{ARO}$ 施行後の 3 年 4 ヶ月 にて抜釬するも，その 7 ヶ月後に骨頭・頚部骨折認め なくなく THA 施行となった（図 4 ）. 

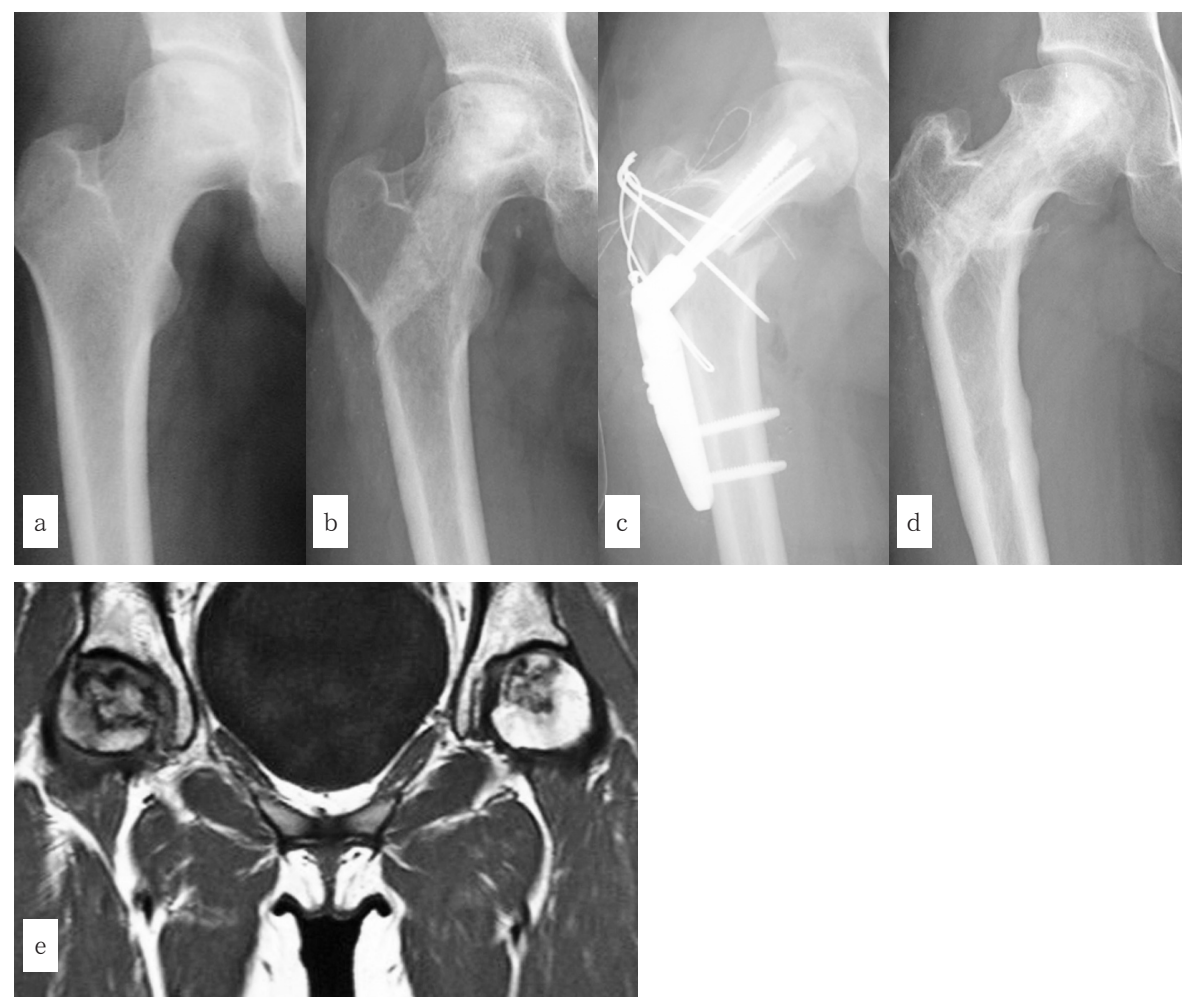

図 2 症例 2

17 歳 女性 血小板減少性紫斑病 TypeC2, stage3B

a. 術前正面

b. 病巣择爬十人工骨移植術後

c. b の術後 4 ヶ月, $\mathrm{ARO}\left(+\right.$ 内反 $\left.10^{\circ}\right)$ 施行 人工骨を含む健常域は $84 \%$

d. 術後 3 年 5 ヶ月後 抜釘術施行

e. MRI 上，両側の大腿骨頭壊死を認め，右股には広範な壊死を示す T1Low band 認める 左は T2FS にて高輝度であり骨頭浮腫を示す

結

果

今回, 我々の症例は, 症例 1 は術後 3 年, 症例 2 が 4 年 2 力月の関節温存が可能であった。症例 3 は左 $\mathrm{ARO}$ 後 4 ヶ月にて右股関節疼痛増強, リハビリ効率, 強固な支持脚を作る目的にて，右 THA 施行。左 $\mathrm{ARO}$ 後 2 年にて抜釘施行し, 約 $5 \mathrm{~mm}$ の骨頭圧潰を 認める屯症状認めない. 症例 4 は術後 4 年 7 ヶ月にて 骨頭頚部骨折来たし THA へ Conversionされた (表 1).

考察

大腿骨回転骨切り術の成績不良因子としては，まず 術後健常部占拠率が $34 \%$ 未満である場合 ${ }^{4)}$ とされ，
これそのものが手術適応を考慮する上で重要な因子と されている。また前方回転骨切り術では屈曲位に壊死 域が荷重部に入り込むいわゆる前後不安定性が問題と される ${ }^{3)}$. また渥美ら ${ }^{2)}$ は術後早期に圧潰を来たす原 因を，血行障害，術前生存域の誤認，早期荷重，予定 の内反・回転の不足, 逆に過度の回転と述べているが, これは術前計画や手術手技に関する要素が多く，本手 術の術前計画や手術手技が困難なことを意味している と考えられる．これらを踏まえて自験例の抜釘後早期 に頚部骨折を来たし, 人工物置換症例を検討すると, 病理組織像では骨䯣壊死像, 壊死骨梁間の肉芽組織を 認め, 修復組織を認めず, 血流障害が示唆された (図 4 ). 前方回転骨切り術の治療成績はすでに多くの 良好な臨床成績が報告されており，当科の有島ら ${ }^{1)}$ 

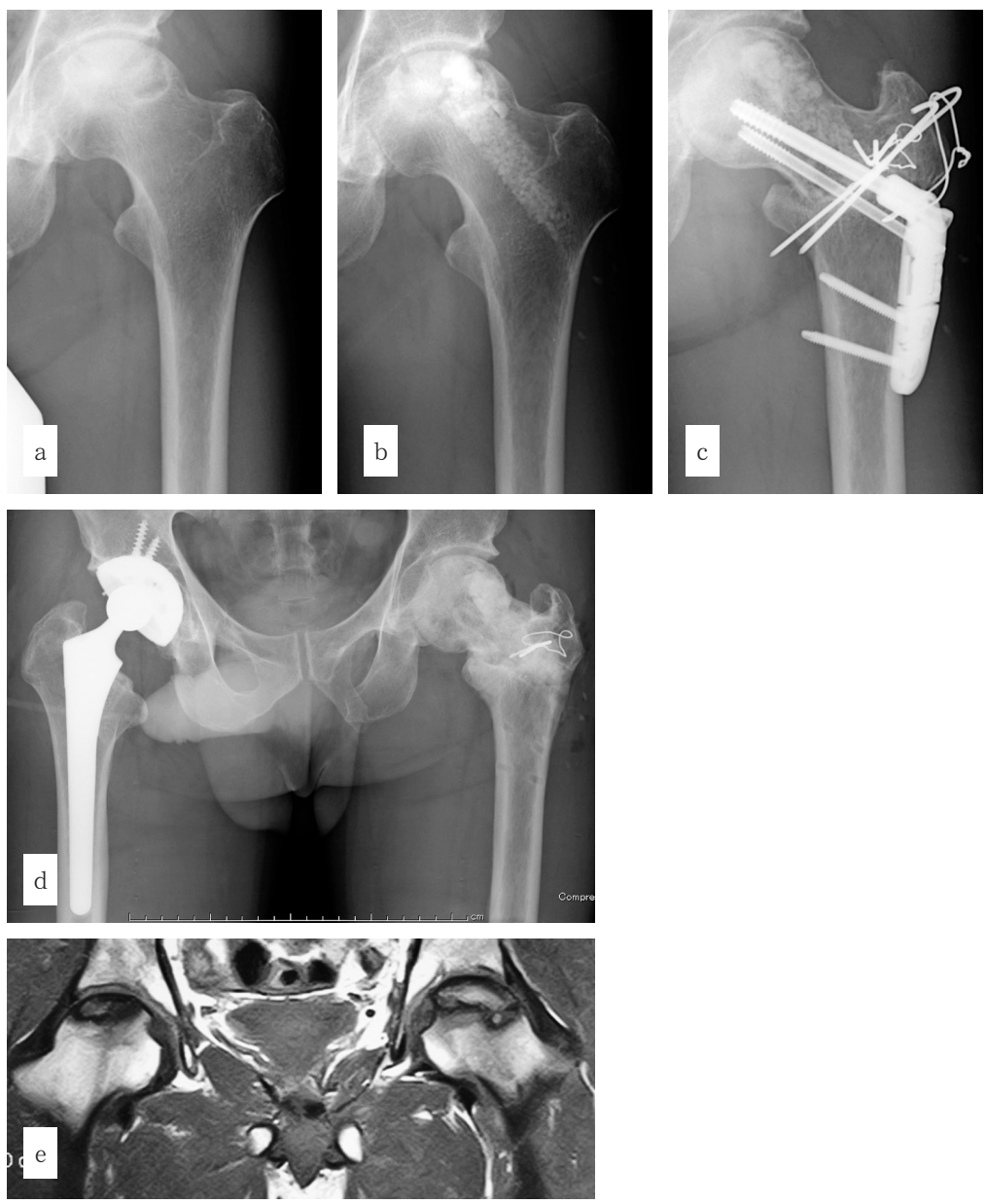

図 3 症例 3
39 歳 男性 原田病（ぶどう膜炎） 右：Type C-1 stage3-A 左：Type C-2 stage3-A
a. 術前正面
b. 病巣择爬十人工骨移植術後
c. b の術後 4 ヶ月, ARO (十内反 $\left.10^{\circ}\right)$ 施行 人工骨を含む健常域は $42 \%$
d. $\mathrm{ARO}$ 術後 4 ヶ月にて右 $\mathrm{THA}$ 施行 $\mathrm{ARO}$ 術後 2 年後に抜釗術施行，軽度の圧潰認める
e. 術前 MRI にて典型的な T1 Low band 認めるが，壊死範囲は広範

治療成績を比較し, stage $3 \mathrm{~A}$ については $77 \%$ の症例 が成績良好例であり，他の報告と遜色ない結果が得ら れたと考えているが, stage 3B については高い確率 で人工物手術にいたる結果となったと述べている。今 回の症例は Stage $3 \mathrm{~A}$ が 3 例, Stage $3 \mathrm{~B}$ が 1 例であ り, そのうち, Stage 3A の症例 3 が THA へ Conversionされた。この症例は, MRI上は骨頭頝部ま で及ぶ広範な壊死範囲を認めた。坂井ら ${ }^{5)}$ は大腿骨頭 壊死症の自然経過について, Type C1 を越える壊死
においては骨頭圧潰による関節症進展の可能性が高い が，一方，活動性が高く，多くはステロイドによる骨 質の問題を抱えた青壮年期の骨頭壊死患者に対する人 工関節置換術は, 可能な限り回避するべきであると述 べている，広範壊死に対する手術法の工夫や後方回転 骨切りを多用することで骨頭温存手術の成績が向上す る可能性があるとの意見もある ${ }^{7)}$ ままた，最近では自 家骨䯣骨単核球移植の有効性も報告されている ${ }^{8)}$. 青 壮年期の大腿骨頭壊死症には可能な限り骨頭温存手術 

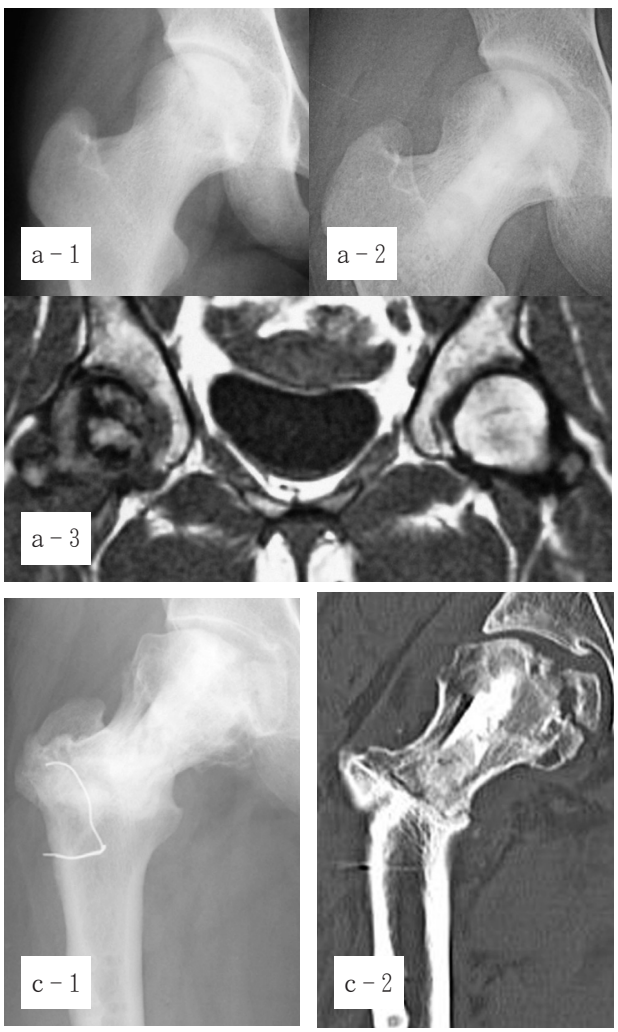
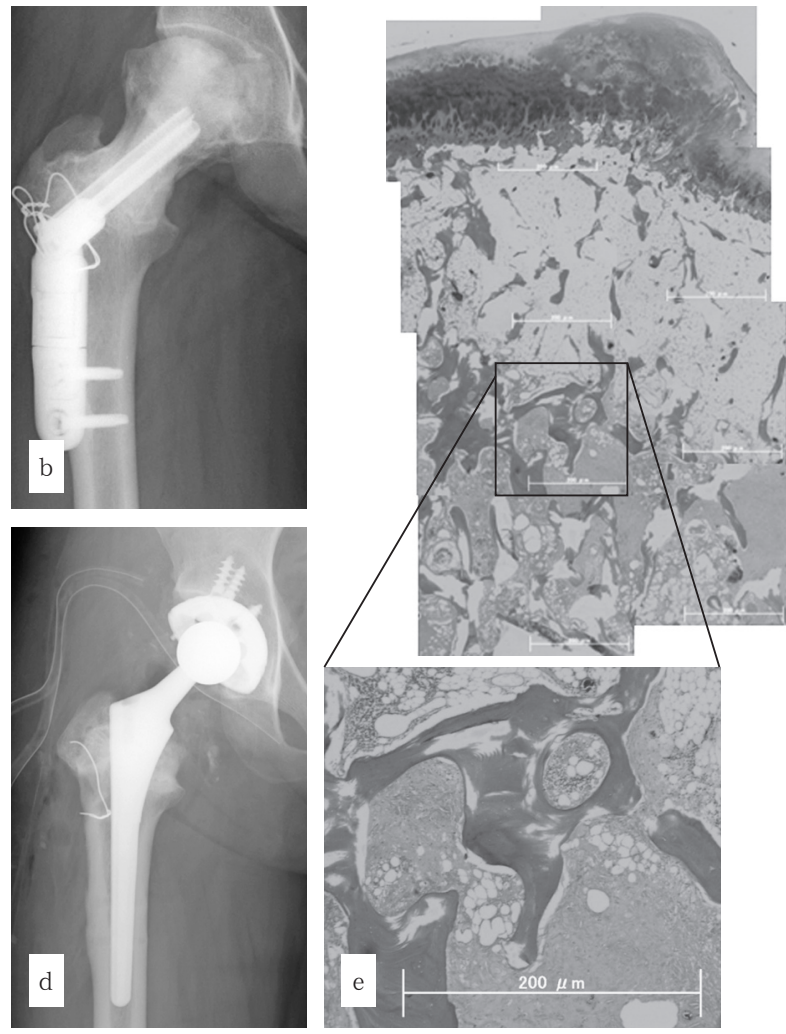

図 4 症例 4

15歳 女性 SLE Type C2 stage3A

a. 1 : 術前正面 2 : 病巣掻爬十人工骨移植術後 3 : MRI にて T1 Low band 認めるが，壊死範 囲は広範で骨頭䅡部に及ぶ

b. 健常部 $52 \%$ a - 2 の術後 4 ヶ月, $\mathrm{ARO}$ 施行

c. $\mathrm{ARO}$ 施行後の 3 年 4 ヶ月にて抜釘するも, $1: \mathrm{X}-\mathrm{p}, 2$ ： CT にて，骨頭および頝部骨折認める

d. 右 THA 施行

e．摘出骨頭の病理所見：骨髄壊死像，壊死骨梁間の肉芽組織を認め，修復組織を認めず，血流障害 が示唆される

\begin{tabular}{|c|c|c|c|c|c|c|c|}
\hline & 初診時年齢 & 性別 & 原疾患 & Type & Stage & 手術 & 関節温存/期間 \\
\hline 症例 1 & 29 & $\mathrm{~F}$ & UC & $\mathrm{C}-2$ & $3-\mathrm{A}$ & $\mathrm{ARO}$ & 温存/ 3 年 \\
\hline 症例 2 & 17 & $\mathrm{~F}$ & ITP & $\mathrm{C}-2$ & $3-B$ & $\mathrm{ARO}$ & 温存/ 4 年 2 ヶ月 \\
\hline 症例 3 & 39 & M & 原田病 & $\mathrm{C}-2$ & $3-\mathrm{A}$ & $\mathrm{ARO}$ & 圧潰進行/ 2 年 8 ヶ月 \\
\hline 症例 4 & 15 & $\mathrm{~F}$ & SLE & $\mathrm{C}-2$ & $3-\mathrm{A}$ & $\mathrm{ARO}$ & THA/ 4 年 7 ヶ月 \\
\hline \multicolumn{8}{|c|}{$\begin{array}{l}\text { UC : Ulcerative Colitis } \\
\text { ITP : Idiopathic Thrombocytopenic Purpura } \\
\text { SLE : Systemic Lupus Erythematosus }\end{array}$} \\
\hline
\end{tabular}


を第一選択に考えているが，その手術適応・方法につ いては今後さらに厳密に検討していく必要がある.

結語

青壮年期の広範囲特発生大腿骨頭壊死症（ION）に 対し，骨髄内择爬扮よび人工骨移植施行後二期的に大 腿骨頭前方回転骨切り術（ARO）を施行した 4 症例 を経験した. Type C2, Stage 3B が 1 例, Type C2, Stage 3A が 3 例であり, その内, Type C2, Stage 3A の症例 4 は $\mathrm{ARO}$ 施行 4 年 7 ヶ月経過後に, THA conversionされた。当教室の広範な骨頭壊死症に対 する人工骨移植術後の二期的大腿骨頭前方回転骨切り 術（ARO）の成績は決して悪いとはいえない。今後 屯, 若年者の広範囲な特発性大腿骨頭壊死症に対して 先進的な方法を含め, 骨頭温存を目指して取り組む必 要があると考える。

\section{参 考 文 献}

1）有島善也ほか：大腿骨頭壊死症に対する転子間回転骨 切り術の治療成績. Hip Joint, 35：341-344, 2009.

2）渥美 敬：大腿骨頭壊死症に対する大腿骨頭回転骨切
り術の適応・術式・成績. Hip Joint，28：8-16，2002.

3) Hiranuma, Y., et al. : Evaluation of instability after transtrochanteric anterior rotational osteotomy for nontraumatic osteonecrosis of the femoral head. J. Orthop. Sci., 14(5) : 535-542, 2009.

4) Miyanishi, K., et al. : Prediction of the outcome of transtrochanteric rotational osteotomy for osteonecrosis of the femoral head. J. Bone Joint Surg., 82-B : 512-516, 2000.

5）坂井孝司ほか：特発性大腿骨頭壊死症に対する関節温 存手術 特発性大腿骨頭壊死症の病期 - 病型分類と予後. Hip Joint, $33:$ 1-3, 2007.

6) Sugioka, Y. : Transtrochanteric anterior rotational osteotomy of the femoral head in the threatment of osteonecrosis affectig the hip. A new osteotomy operation. Clin. Orthop., 130 : 191-201, 1978.

7）山本卓明ほか：大腿骨頭壊死症に対する関節温存手術 の EBM に基づいた適応限界．大腿骨頭壊死症に対する 大腿骨頭回転骨切り術の適応とその根拠. Hip Joint, 31:21-24, 2005.

8) Yamasaki, T., et al. : Transplantation of bone marrow mononuclear cells enables simultaneous treatment with osteotomy for osteonecrosis of the bilateral femoral head. Med. Sci. Monit., 14(4) : CS23-30, 2008. 